\title{
State of polish theatre architecture research in Ukraine
}

\begin{abstract}
The article highlights studying the architecture of Polish theatre in Ukraine and in the world. Peculiarities and differences in researching this issue in foreign and domestic works have been demonstrated. Problems of the research, not taking into consideration versatility and complexity for a thorough presentation, are partially shown in modern works on a quality new level.
\end{abstract}

Key words: Sources, scientific researches, Polish theatre architecture, Ukraine, world

\section{Defining the problem}

Polish ethnos history in Ukraine originates from the creation of the Kyivan Rus, however, $14^{\text {th }}$ century may be considered the most significant stage of its formation on our lands. In the $14^{\text {th }}$ century Kingdom of Galicia-Volhynia, and since mid $16^{\text {th }}$ century - time of Poland and Lithuania uniting into one country - Polish-Lithuanian Commonwealth, according to Union of Lublin (1569) included Volhynia, Bratslavshchyna, Kyiv Region and partially Left-bank Ukraine. At that time mass relocation of Polish people into Ukraine took place and, respectfully, strengthening of Polish culture and education on the territory of our country.

History of both Polish and Ukrainian theatre has not been yet comprehensively presented in scientific works and explorations, therefore, any researches which discuss mentioned issues are still topical and required in Ukrainian, Polish and world scientific practice.

\section{Analysis of recent research and published works}

Systematic and complex research of theatric architecture history in Ukraine has started at the end of the $20^{\text {th }}$ century. Among modern domestic works on the topic it is worth mentioning the fundamental works of a professor $\mathrm{V}$. Proskuriakov and researches by B. Goy, O. Dudka, Yu. Yamash and others $[23 ; 24 ; 6 ; 29]$. Modern foreign and domestic scientific explorations do not show the research of Polish theatre in Ukraine completely but briefly dwell upon the questions of history, culture and art in Ukraine; among them there are works by A. Vypykh-Gavronska, A. Marshalek, O. Palamarchuk, G. Lyzhnytsky, O. Noga, O. Karlina, V. Vytkalov, O. Volosatykh, M. Kostrytsia, P. Pylypchuk and others $[28 ; 21 ; 18 ; 19 ; 22 ; 11]$. In the course of these researches among domestic and foreign publications there has not been found any specific syncretic work dedicated solely to architecture of Polish theatre in Ukraine. For this reason all researched sources have contained only strokes to defining the problems of the work.

\section{Setting the task}

The article is dedicated to research of domestic and foreign historiography of Polish theatre architecture in Ukraine, research of the main peculiarities and differences in presenting given issue in world and Ukrainian works.

\section{Presenting the main material}

Architecture of Polish theatres in Ukraine as a special narrow topic, state of learning which is still on the embryonic level, requires a complex research of a diverse thematics of culture and history of Ukraine on the subject. Taking into consideration the absence of specific works dedicated to architecture of Polish theatres in Ukraine, study of the subject historiography is based on characteristics of works which reveal certain sides to a researched issue. Among domestic publications, most frequently these are works dedicated to history of Ukrainian culture, science and art in general and theatric art; in particular these are works by I. Ohienko, I. Khoma, V. Sheik, Ye. Godovany, G. Luzhnytsky, R. Pylypchuk etc $[12 ; 18 ; 19]$. History of Ukrainian theatre is not studied sufficiently till nowadays, however existing works, highlighting general problems of researched issues, also touch upon the question of the Polish people contribution into cultural and theatric life of Ukraine, in particular these are works by O. Palamarchuk, G. Luzhnytsky, O. Noga, O. Karlina and M. Kostrytsia $[18 ; 19 ; 22 ; 11]$. For instance, strokes of showing the contribution of the Polish people to the culture and history of district cities in Volhynia in the first half of the $19^{\text {th }}$ century can be found in the research by $\mathrm{O}$. Karlina "Theatric life in

*Victor Proskuriakov - Doctor of Architecture, Professor, Dean of Full Education of the Institute of Architecture, Head of Department of Design of Architectural Environment of the Institute of Architecture of Lviv Polytechnic National University (Lviv, Ukraine) 
district cities of Volhynia province in the first half of the $19^{\text {th }}$ century", in the work by G. Luzhnytsky "Ukrainian theatre" their role in theatric life of Ukraine is presented $[11 ; 18 ; 19]$. Scope of works dedicated to research of Polish theatre history in Ukraine is not significant, however, their majority being based on the research of primary sources, archive materials is a valuable scientific acquirement, in particular these are works by P. Gorbatowski, N. Tomazova, V. Filler Ja. Komorowski, S. Kucherepa, T. Gorbachevsky and others [8-10:27:14:17:7]. Among these publications it is worth distinguishing the works dedicated to study of Polish the the in Kyiv. In particula these are the works by N. Bashyndzhahiviv. Stronsy, N. Tomazova [20;27]. Polish theate in Kyiv

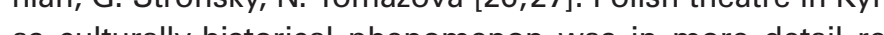
as culturly-historcal phe searched by the following Polish $\checkmark$. Filler, Ja. Komorowski $[8-10 ; 15 ; 16]$. Especially, Polish scientist P. Gorbatowski substantially researched Polish theatric life and functioning of Polish theatre in Kyiv and thematics of Ukrainian-Polish cultural connections at the beginning of the $20^{\text {th }}$ century in his monographs "In claws of politics: Polish theatric life in Kyiv during 1919-1938" and "Polish theatric life in Kyiv during 1905-1918".

Presentation of Polish theatric life in Lviv can be found in the works by Ye. Got, P. Gorbatowski, T. Gorbachevsky, G. Chepnik and V. Kozytsky, Z. Rashevsky, A. Marshalek, A. Vypykh-Gavronska and others $[4 ; 8-10 ; 3 ; 25 ; 21 ; 28]$. The works by Ye. Got "On Guaxary island: Wojciech Boguslawski and Lviv theatre during 1795-1799", G. Chepnik and V. Kozytsky "Lviv stage (1780-1929)", P. Gorbatowski "Polish theatre life during 1939-1946" and T. Gorbachevsky "Polish theatre in Lviv during interwar period of the $20^{\text {th }}$ century" are different chronologically but connected thematically, they make it possible to draw rather detailed pictures of development and activity of Polish theatre in Lviv. In a fragmentary informationa

III. 1. Polish folk theater in Lviv a) facade; a) the plan; b) cut [23]

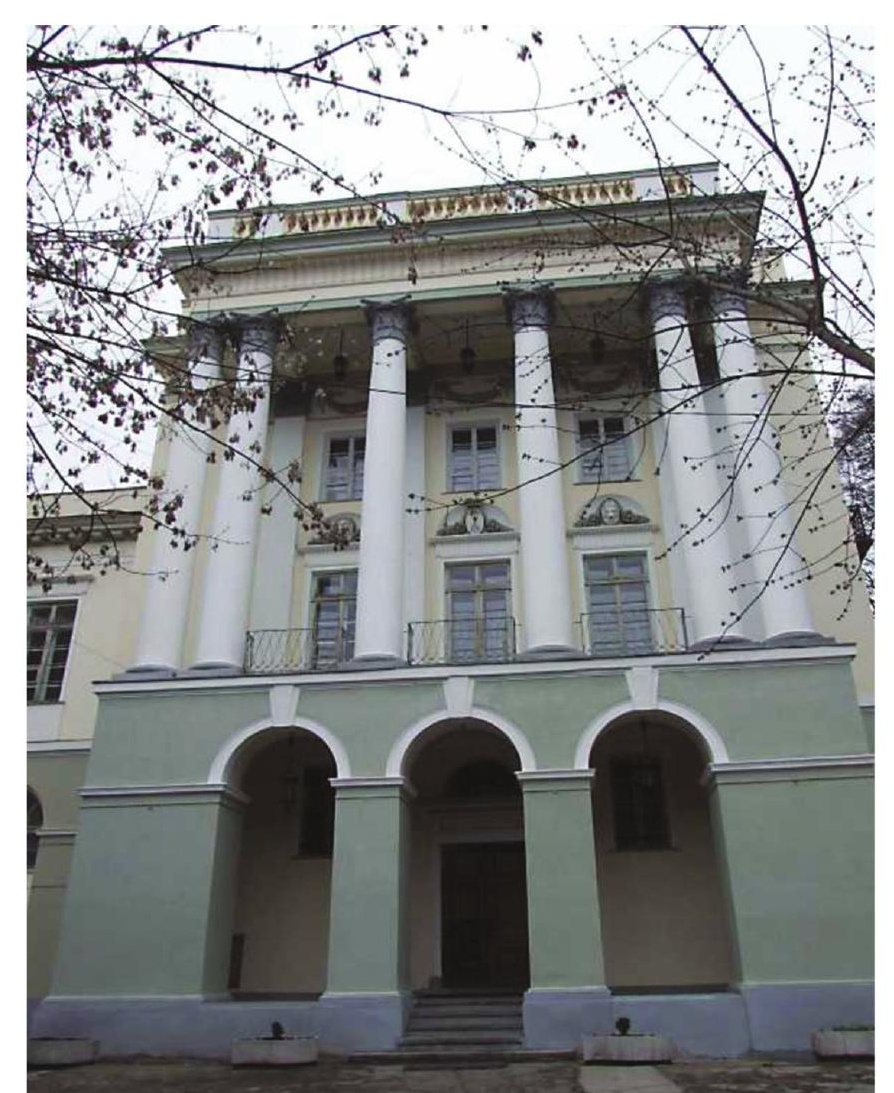

mass on the discussed issue we find a lot of strokes for defining thematics of the research, for example information that in a former canteen of Bielsky palace in Kopernika street (pic. 1 ), built in the $30 \mathrm{~s}$ of the $20^{\text {th }}$ century, since 1959 together with various organizations Polish public theatre was working - one of the firs Lviv theatres which functions out of theatric space. Building architect I. Bagensky couldn't space. Building architect. Bagensky couldn't both public and cultural functions. I. Bagensky created a unique, delicate in proportion and shape to-ondery, delice in propotions would ine would integrally harmonize with surounding architectural envirnent. Centraced staircase was the main interior element of the and bigg rooms and preund $[4,0 ; 7]$. and bigger rooms and premises $[4,9,7]$.

History of Polish theatre in Volhynia was re searched by Ja. Komorowski, S. Kucherepa, A. Bar, in Kamianets-Podilsky by S. Komorowski, in Zhytomyr by S. Komorowski [15-17;1]. Zhytomyr Regional Philharmonic, founded in 1938, is one of interesting theatre buildings which would favour spreading of Polish theatric art (pic. 2). Philharmonic building is situated at 26, Pushkinska str. in a city of Zhytomyr, built in 1858, designed by the proect of a famous architect l. Shtrom was orignally a theatre building. Style - neo-baroque. Initiator of its construction and first directo was a Polish writer-humanist, publisher, his torian, philosopher Jozef Ignacy Kraszewsk (1812-1887). In 1966
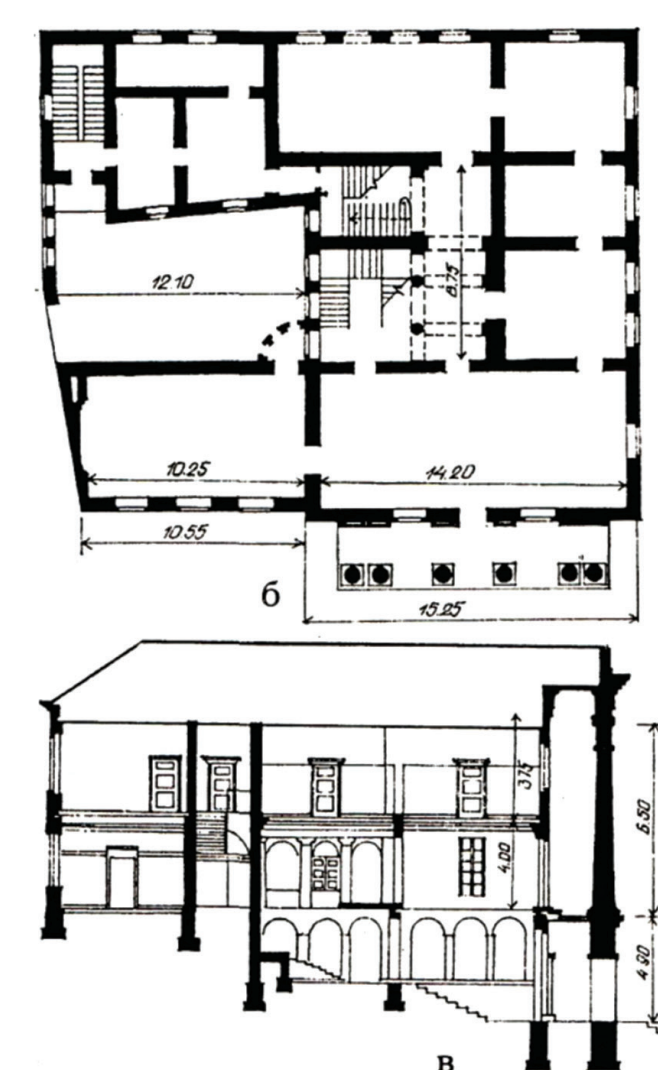

ings and constructions of Ukraine. These are in particular the works by O. Bosak and Ya. Serkiz, A. Bar, Ja. Komorowski and others. For example, there is information that in the $19^{\text {th }}$ century the Polish theatre was located in Dnipro in a profitable house of a nobleman G. Mizko (pic. 4). Built in 1900-1910s by the project of G. I. Panafutin the house occupies the whole quarter of the city in the crossing of Shevchenko str. (Politseyska str. at that time) and Grushko str. (Politseyska str. at that time) and Grushevskogo str. (earlier K. Liebknecht str., at that time - Kazanska str.). At the end of the $19^{\text {th }}$ century this building was one of the most luxurous ones in Katerynoslav. Apart from the accommodations of wealthy residents there was a store of haberdashery of Zolotarewski from Warsaw as well as other institutions. In one of the parts of the building Polish society "Ognisko" and Polish theatre were situated which conducted an active culturally-educational activity, popularized Polish history and culture. After 1917 revolution Mizko building was nationalized by the Council $[2 ; 1 ; 16]$.
Separate details for studying the topic can also be found in the works of historically-ethnographic character which research history and culture of separate territories, cities, theatric build-

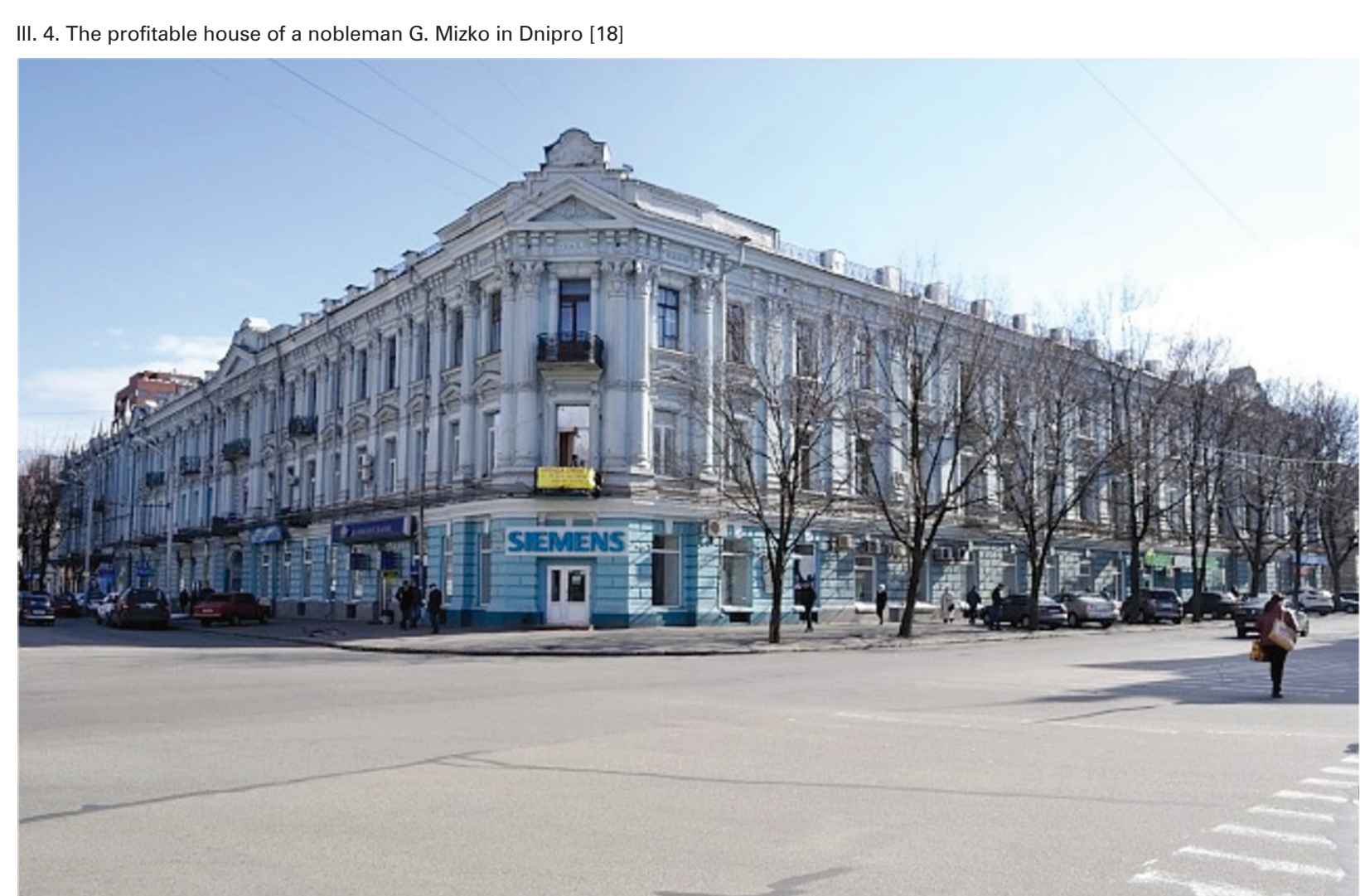


Important facts for highlighting the problems of the reture of theatric buildings and constructions in Ukraine by V. Proskuriakov, L. Luchko, B. Goy, Yu. Yamash $[23 ; 24 ; 5 ; 29]$. A fundamental work about Ukrainian theatre architecture by V. Proskuriakov "Architecture of Ukrainian theatre. Space and action" deserves special attention; not only does it reveal the principles of formation and development of Ukrainian theatric constructions, draws their very phenomenon in time, action and space compared to European theatric achieveme acbut also is one of the first works in domestic science which highlights the aspects of Polish theatre architecture as a sepahighlights one of the first works in domesic science which rate culcula and atistic phenome we have also found information about Polish theatric life in

\section{5. Theater named after $\mathrm{O}$. Fredro in Ivano-Frankivsk: a) a general view; b) a theater plan; c) the plan of the balcony [23]}
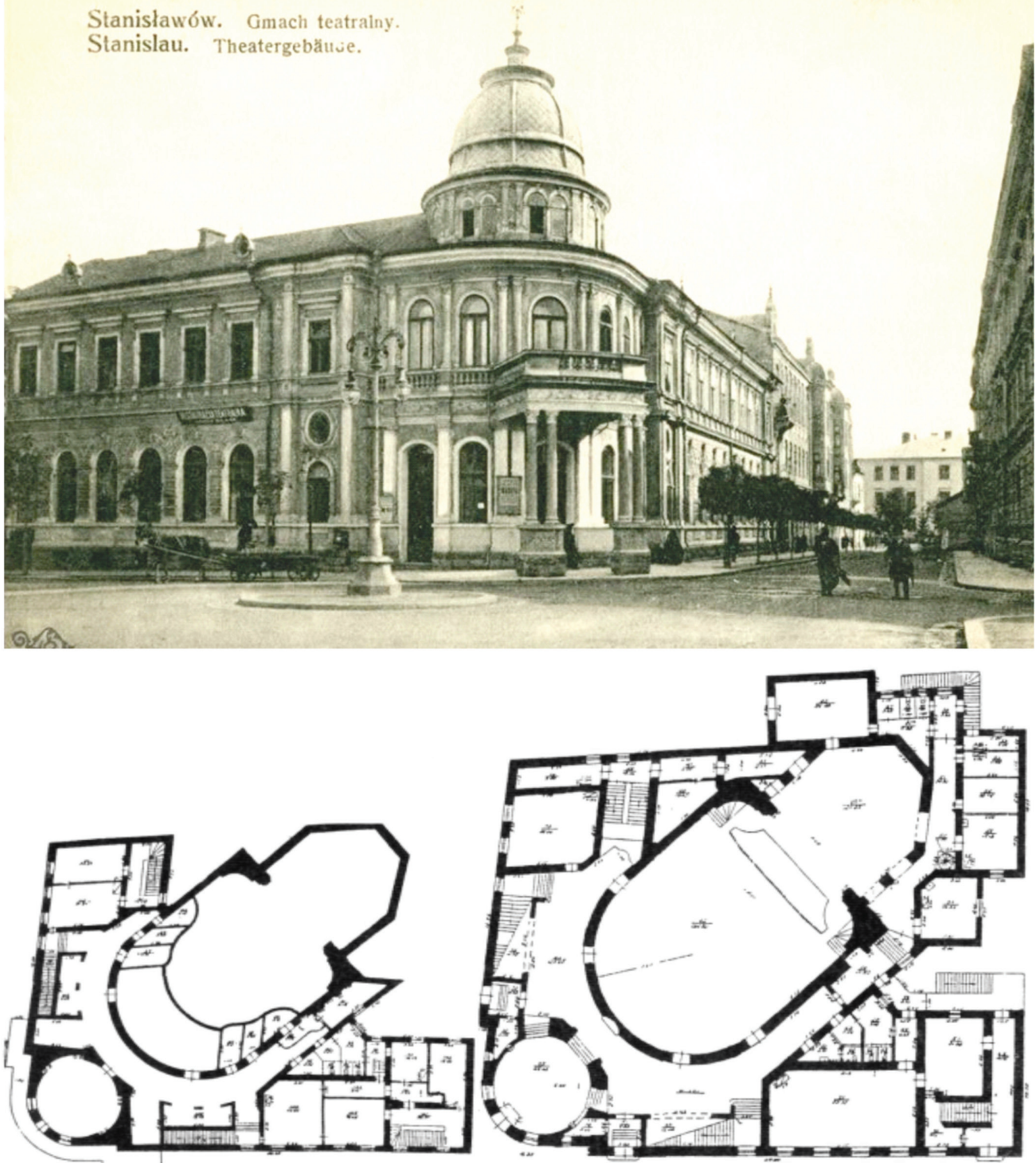

In the array of foreign sources of a similar thematics there has topic. Such studied foreign publications as the works by $Y$ a. Magosci, Z. Kogut, Z. Rashevsky by the example of domestic ones reveal mostly separate aspects of researched topic. Foreign authors usually attempt to find parallels with history and culture of their countries $\{20 ; 13 \cdot 25]$. The peculiarity of these works in content and stylistic division of general conceptul categories into the ones which relate to history and culture of acertain country or the world in general Among the authors of foreign works of a given thematics it is worth mentioning Mershate vypykha will to reveal mosty national questions, and problems in the will to reveal mosty whions restions, and problems in the from archive and pre-war publications etc. [4:21:28].

\section{Conclusions}

Distinguishing scientific research about architecture of Polish theatres from architecture history of Ukraine and Poland into a separom architecture history of Ukraine and Poland and it represents a new stage in the development of both and it represents a new stage in the development of both Ukrainian and Polish science and culture. Including historically-architectural researches of Ukraine into a general culcural context of a state of Ukraine first and then into a world one will assist the development of science and culture and integration process into a world scientific and cultural environment. One of the aspects of researching theatric architecture of Polish community history is uncovering scientific methods of researchers and their conceptions as importan constituents.

For a complete assessment of the research problems the elements of historiography, source-knowing, bibliographic and other works are combined. Without such a work a lot of Ukrainian historically-architectural science achievements are not included into a wide cultural process. Brief overview of works on theatric architecture shows that despite consideran pever Polsh theare archisectere in Ukrane reseach develop mestic and forelgn Polish theate architecture in Ukr aine will make it possible to hightight the key sources for sudying make it possible to highlight the key sources for studying

BIBLIOGRAPHY

11] Bar A. Teatr szlachty wołýnskiej / A. Bar. - Łuck : Nakł. Wotyńskiego t-wa

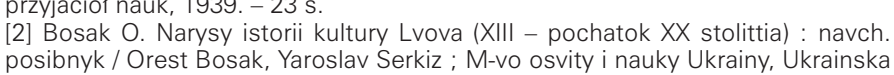

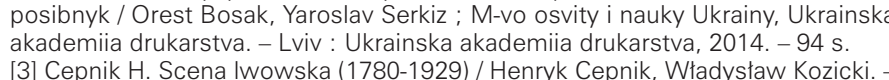
Lwow: Nakladem Gminy, 1929. - 54 Got J. Na wyspie Guaxary: Wojcech Bogustawski i teatr I Iwowski 1789-1799/ 1. Got. - Krakow: Wydawnictwo Literackie, 1971 . - 307 s.

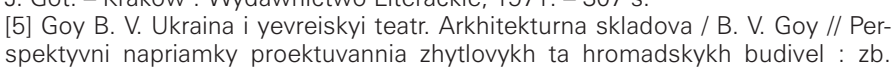

Dauk. prats $/$ pid zan. red. V. V. Kutserycha. - Kyiv. Kyiv ZN[6] Dudka O. M. Tradytsii ta novatorstvo $v$ arkhitekturi khar-

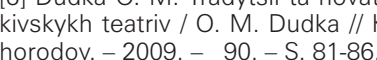
Ti Horbachevskyi T. Polskyi teatr u Lvovi v mizhvoiennyi pe
riod XX stolittia / T. Horbachevskyi // Kraieznavstvo. - 2012. 8] Horbatowski P. Polskie życie teatralne w Kijowie w latach $1905-1918$ / Piotr Horbatowski.-Krakón
wersytetu Jagiellonskiego, 2009 . $-308 \mathrm{~s}$ ch 1939-1946/ Piotr Horbatowski// Teatr Polski we Lwowie. S1997. - S. 10-14. atralne w Kijowie $1919-1938$ / Piotr Horbatowskie ziycie te-
a cyna Naykowa, 1999. - $255 \mathrm{~s}$.

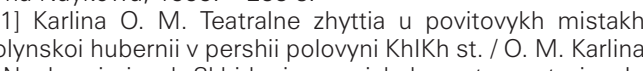
Ukrainky. Istorychni nauky.- Lutsk, 2013.- 21.-S. 27-32.

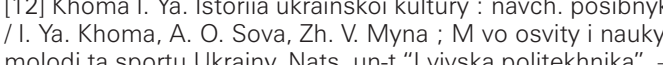
Toronto : Canadian Institute of Ukrainian Studies Press, (4) Komorovskyi Ya. Vumovakh rosiiskoi okupatsii. Polsky
teatr na Volyni, Podilli ta Kyivshchyni v XIX i na pochatk xx st. Y Yarosiav Kom or

15] Komorowski I . Polskie życie teatralne na Podolu i Woty niu do 1863 roku / Jarostaw Komorowski. - Wroctaw : Zakkta 16] Komorowski J. "Teart szlachty wotynskiej - teatr Kra-

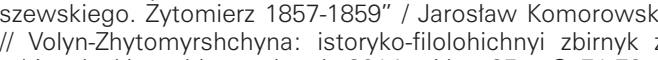
hilonalnykh problem. - Lutsk, 2014. - Vyp. 25. - C. 71-79.
1 17] Kucherepa S. M. Polskyi teatr na Volyni / S. M. Kuchere

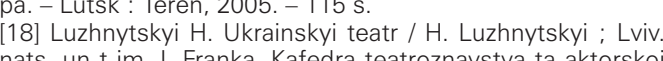
hats. un $t$ im. I. Franka, Kafedra teatroznavstva ta aktorsko
maisternosti, Ukrainskyi vilhyi un-t. - Lviv: [b. v.], 2004. - T. Naukovi pratsi, statti, retsenzii. - 340 s. (19] Luzhnytskyi H. Ukrainskyi teatr / H. Luzhnytskyi ; Lviv
nats. un-tim. I. Franka, Kafedra teatronavstva ta aktorsko

20] Magocsi P. R. A A History of Ukraine / Paul Robert Magoo [21] Marszalek A. Repertuar teatru polskiego we Lwowie w Naukowe Societas Vistulana, 1993. - 215 s

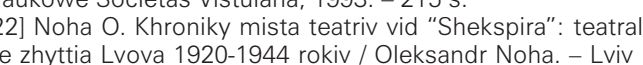
23] Proskuriakov V. I. Arkhitektura ukrainskoho teatru. Prostir 24) Proskuriakov V. Lvivski teatry, Chas i arkhitektura /V. Pro-

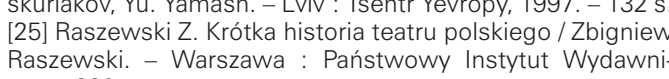
226] Stronskyi H. Polskyi teatr u Kyievi / Henrikh Stronskyi / Ukrainskyi teatr. - 1992. - 5. - S. 28-29.
[27] Tomazova N. Frants Markovskyi: do istorii Polskoho teatru v Kyievi / Nataliia Tomazova // Studii mystetstvoznavchi. 28] Wypych-Gawronska A. Lwowski teatr operowy i operet-
kowy w watach 1872-1918 / A. Wypych-Gawrońska. - Kraków - Trowits,

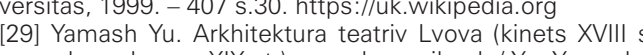
- persha polovyna XIX st.) : navch. posibnyk / Yu. Yamash.
viv: Ib v1.2003 - 190 s. 